УДК 373.3.091.3

DOI:

Олена Ващенко, кандидат педагогічних наук,
доцент кафедри початкової освіти Педагогічного інституту
Київського університету імені Бориса Грінченка

Світлана Паламар, кандидат педагогічних наук, старший науковий співробітник, заступник директора з наукової роботи

Педагогічного інституту Киїського університету імені Бориса Грінченка

Людмила Романенко, кандидат педагогічних наук, стариий викладач кафедри початкової освіти Педагогічного інституту

Київського університету імені Бориса Грінченка

Катерина Романенко, викладач кафедри початкової освіти Педагогічного інституту Київського університету імені Бориса Грінченка

\title{
ТЕОРЕТИЧНИЙ АСПЕКТ ПРОБЛЕМИ ФОРМУВАННЯ ДОСЛІДНИЦЬКИХ УМІНЬ МОЛОДШИХ ШКОЛЯРІВ ЗАСОБОМ ВІРТУАЛЬНОЇ ЕКСКУРСІЇ
}

Стаття присвячена аналізу педагогічних досліджень проблеми формування дослідницьких умінь молодшого школяра засобом віртуальної екскурсії. 3'ясовано, що дослідження зарубіжних та украӥнських педагогів сприяли розробленню методологічних підходів до організачії та здійснення означеної діяльності. Обтрунтовано дочільність використання віртуальних екскурсій як засобу формування дослідницьких умінь дітей. Розкрито сутність базових понять дослідження.

Ключові слова: дослідницькі уміння; віртуальні екскурсї; початкова школа; молодший школяр. Jim. 11.

Olena Vashchenko, Ph.D.(Pedagogy), Associate Professor of the Primary School Education Department, Kyiv Borys Hrinchenko Pedagogical University Svitlana Palamar, Ph.D.(Pedagogy), Senior Research, Deputy Director of Science, Kyiv Borys Hrinchenko Pedagogical University Lyudmyla Romanenko, Ph.D.(Pedagogy), Senior Lecturer of the Primary School Education Department, Kyiv Borys Hrinchenko Pedagogical University Katerina Romanenko, Lecturer of the Primary School Education Department Kyiv Borys Hrinchenko Pedagogical University

\section{THE THEORETICALASPECT OF THE PROBLEM OF FORMATION OF RESEARCH SKILLS OF ELEMENTARY SCHOOL STUDENTS BY VIRTUAL EXCURSION}

The formation of research skills of elementary school students requires the creation of a system that has its own goals and objectives, as well as the creation of a supportive research environment consisting of classrooms, school yards, laboratories focused on the formation of research skills. Research activity is a specially organized cognitive creative activity of students, characterized by purposefulness, proactive attitude, clarity, motivation and consciousness, the result of which is the formation of the students' cognitive motives, research skills, subjective new knowledge or methods of activity.

However, according to the analysis of literary sources and the practical activity of general educational institutions, the problem of organizing and carrying out the research activities of younger students in the study of topics of natural and social orientation remains unsolved. The primary purpose of studying the content of social and health-saving fields in elementary school is to form the students' natural competence by developing a system of integrated knowledge about nature and human. To achieve this goal, the curriculum provides a number of basic tasks, one of which is the formation of research skills and the ability of students to observe objects and phenomena of the animate and inanimate nature.

One of the most effective forms of formation of research skills is excursion. Excursion is a special type of training that is conducted for the direct perception and observation of objects and phenomena of nature, related to the study of program material. Virtual excursion is an organizational form of training that is different from a real excursion by virtual display of real-life objects (museums, parks, city streets, etc.) in order to create the conditions for observation and gathering the necessary facts without assistance.

Keywords: research skills; virtual excursion; an elementary school; an elementary school student.

П остановка проблеми. На сучасному етапі розвитку освіти, відповідно до вимог реформи "Нова українська школа", провідними в навчальних закладах різного рівня $є$ методи і прийоми навчання, засновані на використанні сучасної комп’ютерної техніки та мережі Інтернет.

Одним із методів підвищення інтересу 


\section{ТЕОРЕТИЧНИЙ АСПЕКТ ПРОБЛЕМИ ФОРМУВАННЯ ДОСЛІДНИЦЬКИХ УМІНЬ МОЛОДШИХ ШКОЛЯРІВ ЗАСОБОМ ВІРТУАЛЬНОЇ ЕКСКУРСІЇ}

молодших школярів до оволодіння знаннями про соціум та природу є залучення їх до дослідницької діяльності. Формування дослідницьких умінь учнів початкової школи потребує створення системи, яка б мала свої, притаманні тільки їй, цілі й завдання, а також організація такого сприятливого дослідницького середовища, яке складається з класних приміщень, пришкільних ділянок, лабораторій, зорієнтованих на формування дослідницьких умінь молодших школярів.

Пізнавальна діяльність учнів є важливою складовою організації процесу навчання та набуття ними умінь спостерігати, формулювати гіпотези, проводити досліди, збирати та аналізувати результати, спрямовує на набуття ними відповідних способів мислення, поглядів, цінностей, навичок, здатності до особистісного росту, самореалізації та досягнення життєвого успіху. Формування дослідницьких умінь молодшого школяра має носити системний, поетапний характер, а у подальшому розвиватися та поглиблюватися у основній та старшій школі.

Аналіз останніх досліджень і публікацій Аналіз психолого-педагогічної та методичної літератури засвідчує, що різні аспекти навчальнодослідницької діяльності учнів цікавили багатьох науковців. Теоретичний аспект проблеми розкрито у працях Н. Виноградової, Г. Граника, С. Гончаренка, С. Мартиненко. Формування пізнавальних умінь учнів представлено у дослідженнях В. Андрєєва, Н. Бібік, О. Савченко та ін. Питання дослідницької діяльності вивчали В. Кларін, Л. Левченко, Н. Недодатко, О. Пометун та ін. Проблема формування дослідницьких умінь висвітлювалася у наукових дослідженнях О. Кондратюк, Л. Литовченко, Л. Пироженко, О. Оноприєнко та ін. У зарубіжних працях таких учених, як Ватрхайм Курт, Мак Міллан (Канада), Карсон Деллоса (США), Дітер Крафт (Німеччина), Лінда Бертола (Італія), досліджувалася проблема організації та здійснення науково-дослідницької діяльності молодших школярів.

Однак, як свідчить аналіз літературних джерел та практична діяльність загальноосвітніх закладів, проблема організації та здійснення дослідницької діяльності молодших школярів під час вивчення тем, природничо-соціального спрямування залишається ще недостатньо вирішеною.

Мета статті-проаналізувати стан досліджуваної проблеми у науковій літературі та практиці.

Виклад основного матеріалу. Теоретичний аналіз наукових джерел доводить, що поняття “уміння” $є$ предметом дослідження філософів, психологів і педагогів. За визначенням Педагогічного словника "уміння це - здатність належно виконувати певні дії, яка заснована на доцільному використанні людиною набутих знань і навичок. Уміння передбачає застосування раніше набутого досвіду, певних знань” [8, 94].

У наукових працях 3 психології поняття “уміння” розкривається як сукупність компонентів ключової освітньої компетентності, що представлено цілісною інтегрованою здатністю школяра бути суб' єктом діяльності, яка дозволяє активно і свідомо керувати ходом своєї навчальної діяльності.

В Українському педагогічному словнику під редакцією С. Гончаренка уміння визначаються як “здатність належно виконувати певні діі”. Також зазначається, що “утворення умінь $є$ складним процесом аналітико-синтетичної діяльності кори головного мозку, в ході якого створюються й закріплюються асоціації між завданням, необхідним для його виконання, знаннями та їхнім застосуванням на практиці". У Короткому педагогічному словнику зазначено, що уміння визначається як засвоєний суб'єктом зміст виконання дій, що забезпечуються сукупністю придбаних знань та навичок [3].

Н. Недодатко під навчально-дослідницькими вміннями розуміє складне психічне утворення, синтез інтелектуальних та практичних умінь, що застосовуються для розв'язання навчальнодослідницьких завдань і виникають у результаті управління психічним розвитком учнів $[7,9]$.

Узагальнюючи підходи науковців до визначення поняття “дослідницькі вміння”, робимо акцент на його тлумаченні О. Савченко, яка вважає, що це є вміння планувати і здійснювати науковий пошук, розробляти задум, логіку та програму дослідження, підбирати наукові методи та вміло їх застосовувати, організовувати та здійснювати дослідницько-експериментальну діяльність, обробляти та аналізувати отримані результати, оформляти їх у вигляді наукового тексту, формулювати висновки та успішно їх захищати перед однокласниками та вчителем, а поняття “формування дослідницьких умінь молодших школярів” тлумачимо як цілеспрямований процес діяльності вчителя, кінцева мета якого полягає у спроможності та готовності учня до вирішення поставлених дослідницьких завдань під час вивчення природознавства [11].

У процесі формування дослідницьких умінь молодших школярів важливим є врахування вікових та індивідуальних особливостей учнів; використання ефективних методів навчання; доступність форм і методів дослідження, які застосовуються учнями; відповідність тематики дослідження віковим особливостям та 


\section{ТЕОРЕТИЧНИЙ АСПЕКТ ПРОБЛЕМИ ФОРМУВАННЯ ДОСЛДНИЦЫКИХУМІНЬ МОЛОДШИХ ШКОЛЯРІВ ЗАСОБОМ ВІРТУАЛЬНОЇ ЕКСКУРСЇ̈}

особистісним інтересам учнів; реалізація власних здібностей молодших школярів (саморозвиток, самовдосконалення); потреба учнів у знаннях та розуміння цінності дослідницької діяльності.

Однією з ефективних форм формування дослідницьких умінь під час вивчення довкілля $\epsilon$ екскурсія. Екскурсія - це особливий вид навчальних занять, який проводиться за межами класної кімнати для безпосереднього сприйняття i спостереження учнями об'єктів та явищ природи, пов'язаних з вивченням програмового матеріалу [9].

Найоптимальнішим способом організації навчально-дослідної діяльності учнів $€$ застосування інформаційно-комунікаційних технологій навчання. Поняття “інформаційнокомунікаційні технології навчання (ІКТ)" визначаємо як сукупність методів і технічних засобів реалізації інформаційних технологій на основі комп'ютерних мереж і засобів забезпечення процесу навчання. Інтернет джерела дозволяють визначити “віртуальну екскурсію" як організовану сукупність фото та відео зображень про видатні місця, іноді 3 текстовим або аудіо супроводом та засобами навігації, а також як їі перегляд $[1 ; 2 ; 6]$.

Таким чином, “віртуальна екскурсія” - це організована форма навчання, яка відрізняється від традиційної навчальної екскурсії віртуальним відображенням реально існуючих об'єктів соціуму та природи 3 метою створення умов для самостійного спостереження в довкіллі, збору необхідних фактів.

У процесі формування дослідницьких умінь учнів важливу роль відіграють принципи: інтегрованості (об’єднання і взаємовплив навчальної і дослідницької діяльності учнів, коли досвід і навички безпосередньо впливають на успішність учнів); неперервності (процес довготривалого навчання і виховання, що проявляється, перш за все, в творчому об'єднанні учнів та вчителів); міжпредметних зв'язків (дослідження будь-якої проблеми вимагає знання досліджуваного предмета та широку ерудицію під час вивчення всіх навчальних дисциплін). Саме тому в процесі формування дослідницьких умінь молодших школярів доцільно застосовувати різноманітні форми, методи та засоби діяльності, що відповідають поставленій меті. У процесі заохочення молодших школярів до навчальнодослідної діяльності перед учителем постає проблема організації вирішення єдиних дослідних завдань при різному рівні розвитку дослідницького досвіду учнів. У вирішенні цієї проблеми вчителіпрактики обирають такі прийоми і форми роботи, які дозволяють учням використати та збагатити свій індивідуальний дослідницький досвід. Зрозуміло, що більш доцільним є організація дослідницької діяльності учнів на уроках “ $Я$ досліджую світ”, оскільки цьому сприяє сам досліджуваний природничий матеріал. Однією 3 ефективних форм формування дослідницьких умінь під час вивчення тем природничосоціального спрямування є екскурсія.

Для ефективного формування дослідницьких умінь молодших школярів у ході проведення екскурсій доцільним є врахування таких вимог: чітке визначення навчальної, виховної та розвивальної мети; правильний вибір місця проведення екскурсії (наявність тих природничих об'єктів, за якими учні будуть спостерігати та досліджувати їхні ознаки); психологічне налаштування школярів на здійснення дослідницької діяльності в природі; підбір групових та індивідуальних завдань, що включатимуть елементи спостережень та дослідження; використання дидактичних ігор; привернення уваги до проблеми соціуму та екології та дослідження умов вирішення соціальних та природоохоронних проблем; оформлення звітів у вигляді дослідницьких письмових робіт, гербаріїв, леп буків, презентацій тощо. Наприклад, в інтегрованому курсі “Я досліджую світ” можуть бути проведені екскурсії населеним пунктом, у природу (ліс, парк, сад), природничий музей, будинок природи, планетарій, по історичним місцям рідного краю тощо [9].

Не менш важливим у процесі формування дослідницьких умінь учнів $є$ розв'язання проблемних завдань під час вивчення об'єктів живої й неживої природи. Методи проблемного викладу дозволяють учням оволодівати досвідом дослідницької діяльності, яка пов'язана 3 виникненням і вирішенням навчальної проблеми. Навчальна проблема - це штучна педагогічна конструкція, яка моделюється учителем у структурі змісту навчального предмету. Навчальна проблема - це знання про незнання, усвідомлення того, що необхідно дізнатися, пояснити, встановити. Для вирішення навчальної проблеми варто підбирати та пропонувати різні види проблемних завдань: проблемні завдання на виявлення ознак та властивостей природничих предметів (вивчення ознак і властивостей відбувається за допомогою проведення дослідів); проблемні завдання на засвоєння нових понять про природничі предмети і явища; проблемні завдання на встановлення взаємозв'язків та залежностей між об'єктами природи; проблемні завдання на засвоєння нових природничих знань за допомогою дослідження [10]. 


\section{ТЕОРЕТИЧНИЙ АСПЕКТ ПРОБЛЕМИ ФОРМУВАННЯ ДОСЛІДИЦЬКИХ УМІНЬ МОЛОДШИХ ШКОЛЯРІВ ЗАСОБОМ ВІРТУАЛЬНОӤ ЕКСКУРСІЇ}

Ефективним методом процесу формування дослідницьких умінь молодших школярів $є$ дослідницькі проекти. Проектна діяльність є надзвичайно перспективною, оскільки, беручи в ній участь, кожен із учасників не втрачає свого статусу активної особистості, намагається зайняти в групі позицію, що відповідає його можливостям: знанням, умінням, здібностям, мисленню тощо. Це позначається на загальному формуванні індивідуальності учня. Працюючи над проектом учні спілкуються, співпрацюють допомагають один одному в процесі навчання, розвивають соціальні, інтелектуальні та комунікативні навички. Цей вид діяльності сприяе здійсненню індивідуального підходу в класах 3 різним рівнем підготовки під час вивчення та засвоєння нового матеріалу. Метою методу проекту є створення умов, за яких учні самостійно й охоче отримують знання 3 різних джерел, вчаться користуватися ними (знаннями) для розв'язання нових пізнавальних і практичних завдань, удосконалюють комунікативні вміння, працюючи в різних групах, що сприяє формуванню в них як дослідницьких умінь, так і аналітичного мислення. Наприклад, темами дослідницьких проектів можуть бути такі: “Чому вода має бути чистою?”, “Цукор - друг чи ворог?”, “Зелене диво рідного краю”, "Гроші національного банку України", "Українські музеї просто неба" $[4,5]$.

Аналіз наукової літератури дозволяє зробити висновок, що в процесі формування дослідницьких умінь учнів під час вивчення інтегрованого курсу "Я досліджую світ" потрібно дотримуватися таких послідовних етапів: вибір теми; постановка мети і завдань дослідження; планування дослідження та вибір методів; пошук інформації; проведення дослідів, опитувань, створення графіків і діаграм; формулювання висновків та представлення результатів; аналіз своєї діяльності та самооцінка; публічне представлення результатів на різного виду заходах (конференціях, звітах, читаннях тощо)

Проведений нами аналіз наукових досліджень також дозволив виокремити такі види дослідницьких умінь, що формуються у молодших школярів: організаційні (вміння організовувати свою роботу під час проведення спостережень за об’єктами живої й неживої природи); пошукові (вміння здійснювати дослідження, виявляти властивості та ознаки природничих об'єктів); інформаційні (вміння працювати з інформацією, що вміщена в енциклопедіях, навчальних текстах про природу); оціночні (вміння аналізувати свою діяльність, представляти результат свого дослідження) [7; 10; 11]. 3'ясовано, що в ході здійснення дослідницької діяльності учні вчаться визначати тему дослідження, аналізувати, порівнювати, формулювати висновки, оформляти результати дослідження. Процес формування дослідницьких умінь молодших школярів може складатися 3 таких методів і способів діяльності: обговорення в групі, спостереження за планом, мінідослідження, екскурсії, індивідуальне складання моделей і схем, міні-доповіді, рольові ігри, експерименти

Отже, в процесі формування дослідницьких умінь у молодших школярів важливим $є$ врахування вікових та індивідуальних особливостей учнів; використання ефективних методів навчання; доступність форм і методів дослідження, що проводяться молодшими школярами; відповідність тематики дослідження віковим особливостям та особистісним інтересам учнів. В ході здійснення означеної діяльності відбувається реалізація власних здібностей молодших школярів, їхній саморозвиток та самовдосконалення, враховується потреба учнів у знаннях та розуміння цінності дослідницької діяльності.

Висновки. Гуманістичні пріоритети сучасної освіти, зокрема її початкової ланки, грунтуються на ідеях унікальності особистості, необхідності розвитку їі пізнавальних інтересів і творчих здібностей, задоволенні освітніх потреб завдяки залученню до дослідницької діяльності.

Основною метою вивчення в початковій школі змісту соціальної та здоров'язбережувальної галузі $\epsilon$ формування природознавчої компетентності учнів завдяки засвоєнню системи інтегрованих знань про природу і людину. Для досягнення зазначеної мети навчальною програмою передбачено розв'язання ряду основних завдань, одним 3 яких $\epsilon$ формування дослідницьких умінь та умінь учнів спостерігати за об'єктами та явищами живої і неживої природи. Однією 3 ефективних форм формування дослідницьких умінь $є$ віртуальна екскурсія.

Отже, аналіз наукової літератури довів, що формування дослідницьких умінь молодших школярів засобом віртуальної екскурсії є одним із пріоритетних компонентів освітнього процесу, що має важливе значення для практичної діяльності учнів. Водночас, у початковій школі ще недостатньо застосовуються можливості віртуальної екскурсії як засобу формування дослідницьких умінь молодших школярів.

\section{ЛІТЕРАТУРА}

1. Виртуальные экскурсии и 3d-путешествия. URL: http://www.panotours.ru/ 


\section{ТЕОРЕТИЧНИЙ АСПЕКТ ПРОБЛЕМИ ФОРМУВАННЯ ДОСЛДНИЦЫКИХУМІНЬ МОЛОДШИХ ШКОЛЯРІВ ЗАСОБОМ ВІРТУАЛЬНОЇ ЕКСКУРСІЇ}

2. Виртуальные экскурсии? Почему бы и нет? U R L : h t t p s : / / e d u g l ax y.intel. ru / ?automodule $=$ blog\&blogid $=1718 \&$ showentry $=1165$

3. Гончаренко С. Український педагогічний словник. Київ, 1997. 376 с.

4. Іщенко О.Л., Ващенко О.М., Романенко Л.В., Романенко К.А., Кліщ О.М. Я досліджую світ : підруч. для 2 кл. закл. загал. серед. освіти (у 2-х частинах) : Ч. 1, 2. Київ, 2019. 112 с.

5. Іщенко О.Л., Ващенко О.М., Романенко Л.В., Романенко К.А., Кліщ О.М. Я досліджую світ : підруч. для 1 кл. закл. загал. серед. освіти (у 2-х частинах) : Ч. 1 Київ, 2018. 112 с.

6. Кадемія М.Ю., Козяр М.М., Рак Т.Є. Інформаційно-комунікаційні технології навчання: словник-глосарій. Львів, 2011. 327 с.

7. Недодатко Н.Г. Формування навчальнодослідних умінь старшокласників: автореф. дис. ... канд. пед. наук: спец. 13.00.09 “Теорія навчання". Харків, 2000. 25 с.

8. Педагогічний словник / за ред. М.Д. Ярмаченка Київ, 2001.514 с.

9. Подобєд О. Віртуальні навчальні екскурсії історичними просторами України та зарубіжних країн. Історія в сучасній школі. 2012. №6. С. 2629.

10. Романенко К.А. Змістово-технологічне забезпечення спостережень учнів початкової школи на уроках природознавства. Початкова освіта: історія, проблеми, перспективи: матеріали Міжнародної науково-практичної конференції, м. Ніжин, 20-21 жовтня 2016 р. Ніжин, 2016. 163 с.

11. Савченко О.Я. Уміння вчитися як ключова компетентність. Компетентнісна освіта: від теорії до практики. Київ, 2005. С. 4-20.

\section{REFERENCES}

1. Virtualnyye ekskursii $i$ 3d-puteshestviya [Virtual excursions and 3D-journeys]. Available at: http://www.panotours.ru [in Russian].

2. Virtualnyye ekskursii? Pochemu by $i$ net? [Virtual excursions? Why not?]. Available at: https:// ed u g a laxy. in te l. ru/? a u t o module $=$ blog\&blogid $=1718 \&$ showentry $=1165$ [in Russian].

3. Honcharenko, S. (1997). Ukrainskyi pedahohichnyi slovnyk [Ukrainian pedagogical dictionary]. Kyiv, 376 p. [in Ukrainian].
4. Ishchenko, O.L., et al. (2019). Ya doslidzhuiu svit : pidruch. dlia $2 \mathrm{kl}$. zakl. zahal. sered. osvity (u 2-kh chastynakh) : Ch. 1, 2 [I am exploring the world : schoolbook for $2^{\text {nd }}$ grade of institutions of general secondary education: Issues 1, 2]. Kyiv, 112 p. [in Ukrainian].

5. Ishchenko, O.L., et al. (2018). Ya doslidzhuiu svit : pidruch. dlia $1 \mathrm{kl}$. zakl. zahal. sered. osvity (u 2-kh chastynakh) [I am exploring the world : schoolbook for $1^{\text {st }}$ grade of institutions of general secondary education]. issue 1 . Kyiv, $112 \mathrm{p}$. [in Ukrainian].

6. Kademiia, M.Iu., Koziar, M.M. \& Rak, T.Ie (2011). Informatsiino-komunikatsiini tekhnolohii navchannia: slovnyk-hlosarii [Informational communicational educational technologies: dictionaryglossary]. Lviv, 327 p. [in Ukrainian].

7. Nedodatko, N.H. (2000). Formuvannia navchalno-doslidnykh umin starshoklasnykiv [The formation of educational-research skills of high school]. Extended abstract of candidate's thesis. Kharkiv, 25 p. [in Ukrainian].

8. Pedahohichnyi slovnyk (Ed.).Yarmachenko M.D. (2001). [Pedagogical dictionary]. Kyiv, 514 p. [in Ukrainian].

9. Podobied, O. (2012). Virtualni navchalni ekskursii istorychnymy prostoramy Ukrainy ta zarubizhnykh krain [Virtual educational excursions of historical places of Ukraine and foreign countries]. History in modern school. No. 6, pp. 26-29. [in Ukrainian].

10. Romanenko, K.A. (2016). Zmistovotekhnolohichne zabezpechennia sposterezhen uchniv pochatkovoi shkoly na urokakh pryrodoznavstva [Substantive and technological support for observations of elementary school students during natural science lessons]. Pochatkova osvita: istoriia, problemy, perspektyvy: materialy Mizhnarodnoi naukovo-praktychnoi konferentsii, m. Nizhyn, 20-21 zhovtnia 2016 r. - Elementary education: history, problems, prospects: Proceedings of the International Scientific-Practical Conference, Nizhin, October 20-21, 2016. Nizhin, 163 p. [in Ukrainian].

11. Savchenko, O.Ia. (2005). Uminnia vchytysia yak kliuchova kompetentnist [Ability to learn as a key competence]. Competency education: from theory to practice. Kyiv, pp. 4-20. [in Ukrainian].

Стаття надійшла до редакції 27.09.2019

\section{G5808NC2058080

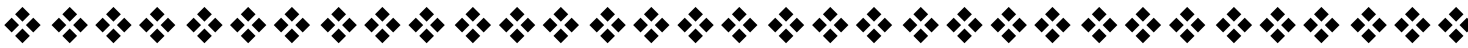

